\title{
New records of Speothos venaticus Lund, 1842 (Carnivora: Canidae) in the state of Pará, Brazil
}

\author{
Guimarães, VY. ${ }^{*}$, Cesca, LCC. ${ }^{a}$, Trombin, DF. ${ }^{a}$ and Pinder, L. ${ }^{b}$ \\ aBiota Projetos e Consultoria Ambiental Ltda., Rua 86 C, 64, Setor Sul, CEP 74083-360, Goiânia, GO, Brazil

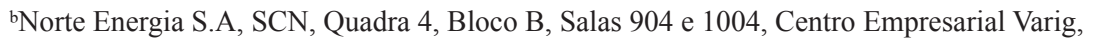 \\ CEP 70714-900, Brasília, DF, Brazil \\ *e-mail: medvetyunes@gmail.com
}

Received: May 2, 2014 - Accepted: July 14, 2014 - Distributed: August 31, 2015

(With 1 figure)

The Bush dog (Speothos venaticus, Lund, 1842) is the smallest Brazilian canid. The species lives in groups of two to twelve individuals and is considered the most social of the neotropical canids (Burton et al., 1988). Individuals are capable of swimming and diving while foraging and usually can be found near streams. For resting, bush dogs look for shelter in armadillo burrows and hollow tree trunks.

Over the years, the bush dog population has declined due to habitat loss (Emmons and Feer, 1990; MacDonald, 1996; Beisiegel and Zuercher, 2005; Zuercher et al., 2005; Michalski, 2010). However, Oliveira (2009) refutes the hypothesis that the species is sensitive to habitat disturbance as $43 \%$ of total records for the species occurred in areas with high levels of natural habitat fragmentation.

Until 2004, the species was listed as Vulnerable according to the criteria of the International Union of Conservation of Nature (IUCN) (DeMatteo and Loiselle, 2008) and in the Appendice I of CITES (Convention on International Trade and Endangered Species of Wild Fauna and Flora), but actually it is in the category "Near Threatened" on a global scale (DeMatteo et al., 2011).

In Brazil, the species is stated as "Vulnerable" according to the official list of threatened species, occurs in different biomes such as Atlantic Forest, Cerrado, Pantanal and the Amazon, where is classified as "Vulnerable" (Jorge et al., 2013).

The new records of bush dog presented in this article were obtained during the wildlife rescue and monitoring operations of the Belo Monte's Hydroelectric Power Plant Basic Environmental Plan. Data were collected from June 2011 to March 2014 (Table 1), in the region known as "Volta Grande do Xingu", located in the lower Xingu River region between the cities of Altamira and Vitoria do Xingu, PA (Figure 1).

Further analysis of habitat quality and connectivity will help not only to better understand the ecology of the species, but also to promote its conservation by habitat protection and restoration in the area.

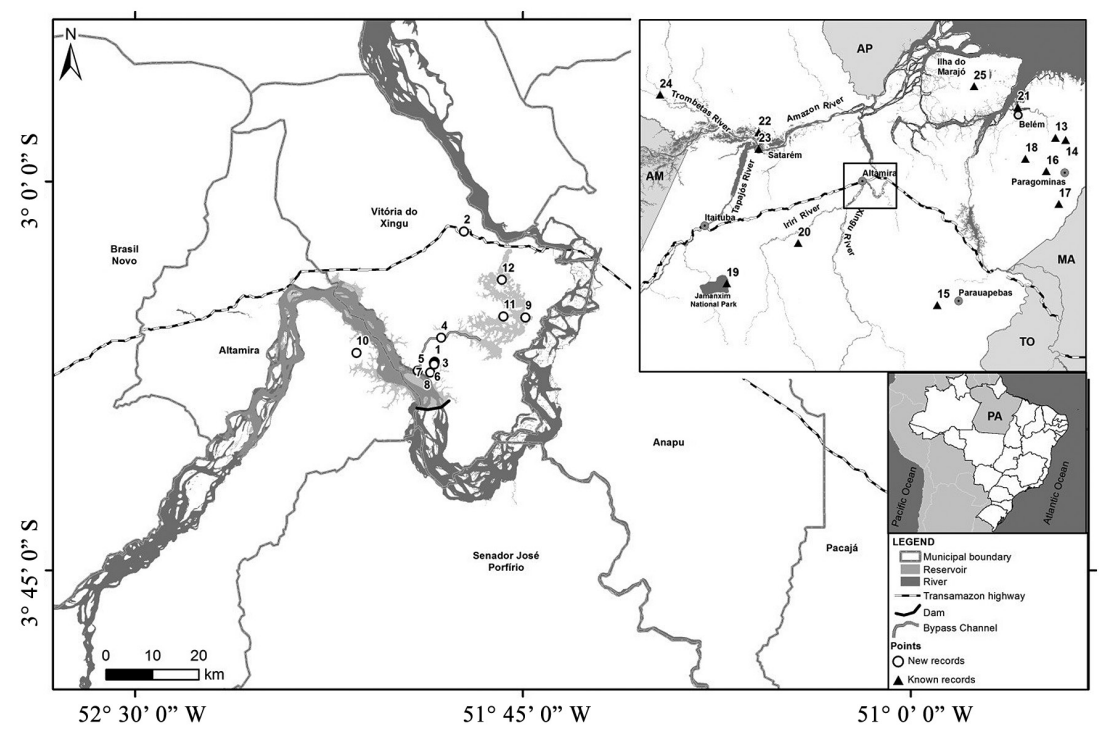

Figure 1. Bush dog distribution in the state of Pará, Brazil. 
Table 1. Records of specimens Bush Dogs in state of Pará, Brazil.

\begin{tabular}{|c|c|c|}
\hline Type of Record & Coordinates & Source \\
\hline 1. Capture/ Radio tracking & $3^{\circ} 20^{\prime} \mathrm{S} 51^{\circ} 55^{\prime} \mathrm{W}$ & UHE Belo Monte \\
\hline 2. Roadkill & $3^{\circ} 05^{\prime} \mathrm{S} 51^{\circ} 51^{\prime} \mathrm{W}$ & UHE Belo Monte \\
\hline 3. Sighting & $3^{\circ} 20^{\prime} \mathrm{S} 51^{\circ} 55^{\prime} \mathrm{W}$ & UHE Belo Monte \\
\hline 4. Sighting & $3^{\circ} 18^{\prime} \mathrm{S} 51^{\circ} 54^{\prime} \mathrm{W}$ & UHE Belo Monte \\
\hline 5. Sighting & $3^{\circ} 21^{\prime} \mathrm{S} 51^{\circ} 57^{\prime} \mathrm{W}$ & UHE Belo Monte \\
\hline 6. Sighting & $3^{\circ} 21^{\prime} \mathrm{S} 51^{\circ} 55^{\prime} \mathrm{W}$ & UHE Belo Monte \\
\hline 7. Sighting & $3^{\circ} 22^{\prime} \mathrm{S} 51^{\circ} 55^{\prime} \mathrm{W}$ & UHE Belo Monte \\
\hline 8. Roadkill & $3^{\circ} 22^{\prime} \mathrm{S} 51^{\circ} 55^{\prime} \mathrm{W}$ & UHE Belo Monte \\
\hline 9. Capture/ Radio tracking & $3^{\circ} 15^{\prime} \mathrm{S} 51^{\circ} 44^{\prime} \mathrm{W}$ & UHE Belo Monte \\
\hline 10. Sighting & $3^{\circ} 19^{\prime} \mathrm{S} 52^{\circ} 04^{\prime} \mathrm{W}$ & UHE Belo Monte \\
\hline 11. Sighting & $3^{\circ} 15^{\prime} \mathrm{S} 51^{\circ} 47^{\prime} \mathrm{W}$ & UHE Belo Monte \\
\hline 12. Unknown & $2^{\circ} 10^{\prime} \mathrm{S} 47^{\circ} 35^{\prime} \mathrm{W}$ & Carvalho and Toccheton (1969) apud Oliveira (2009) \\
\hline 13. Sighting & $2^{\circ} 13^{\prime} \mathrm{S} 47^{\circ} 20^{\prime} \mathrm{W}$ & Lopes and Ferrari (2000) \\
\hline 14. Records of Museum & $6^{\circ} 10^{\prime} \mathrm{S} 50^{\circ} 25^{\prime} \mathrm{W}$ & Zuercher et al. (2004) \\
\hline 15. Unknown* & $2^{\circ} 58^{\prime} \mathrm{S} 47^{\circ} 48^{\prime} \mathrm{W}$ & Oliveira (2009) \\
\hline 16. Unknown* & $3^{\circ} 45^{\prime} \mathrm{S} 47^{\circ} 30^{\prime} \mathrm{W}$ & Oliveira (2009) \\
\hline 17. Unknown* & $2^{\circ} 40^{\prime} \mathrm{S} 48^{\circ} 18^{\prime} \mathrm{W}$ & Oliveira (2009) \\
\hline 18. Personal Communication & $5^{\circ} 39^{\prime} \mathrm{S} 55^{\circ} 28^{\prime} \mathrm{W}$ & Oliveira (2009) \\
\hline 19. Personal Communication & $4^{\circ} 41^{\prime} \mathrm{S} 53^{\circ} 45^{\prime} \mathrm{W}$ & Oliveira (2009) \\
\hline 20. Records of Museum & $1^{\circ} 26^{\prime} \mathrm{S} 48^{\circ} 29^{\prime} \mathrm{W}$ & MPEG 1778, 1780 - Oliveira (2009) \\
\hline 21. Records of Museum & $2^{\circ} 02^{\prime} \mathrm{S} 54^{\circ} 18^{\prime} \mathrm{W}$ & MPEG 5614, 5615, 8791, 8793 - Oliveira (2009) \\
\hline 22. Interview & $2^{\circ} 26^{\prime} \mathrm{S} 54^{\circ} 42^{\prime} \mathrm{W}$ & Sampaio (2007) \\
\hline 23. Records of Museum & $1^{\circ} 08^{\prime} \mathrm{S} 57^{\circ} 04^{\prime} \mathrm{W}$ & Zuercher et al. (2004) \\
\hline 24. Records of Museum & $0^{\circ} 56^{\prime} \mathrm{S} 49^{\circ} 32^{\prime} \mathrm{W}$ & **MPEG 26180 - Silva-Junior and Soares (1999) \\
\hline
\end{tabular}

*This author does not describe the type of the record. **MPEG, Museu Paraense Emílio Goeldi, Belém, Brazil.

\section{Acknowledgements}

Thanks to Norte Energia, Biota Projetos e Consultoria Ambiental for logistical support during field activities and all biologists that contributed in some way towards this study.

\section{References}

BEISIEGEL, BM. and ZUERCHER, GL., 2005. Speothos venaticus. Mammalian Species, vol. 783, p. 1-6. http://dx.doi. org/10.1644/783.1.

BURTON, JA., PEARSON, B. and SCOTT, P., 1988. The Collins guide to the rare mammals of the World. New York: The Stephen Greene Press. 240 p.

DEMATTEO, KE. and LOISELLE, BA., 2008. New data on the status and distribution of the bush dog (Speothos venaticus): evaluating its quality of protection and directing research efforts. Biological Conservation, vol. 141, no. 10, p. 2494-2505. http:// dx.doi.org/10.1016/j.biocon.2008.07.010.

DEMATTEO, KE., MICHALSKI, F. and LEITE-PITMAN, MRP., 2011. Speothos venaticus. In IUCN Global Species Programme Red List Unit. IUCN Red List of threatened species. Version 2011.2. Cambridge. Available from: <www.iucnredlist.org>. Access in: 15 Apr. 2014.

EMMONS, LH. and FEER, F., 1990. Neotropical rainforest mammals: a field guide. Chicago: University Chicago Press. 281 p.
JORGE, RPS., BEISIEGEL, BM., LIMA, ES., JORGE, MLPS., LEITE-PITMAN, MRP. and PAULA, RC., 2013. Avaliação do Estado de Conservação do Cachorro-Vinagre Speothos venaticus (Lund, 1842) no Brasil. Biodiversidade Brasileira, vol. 3, no. 1, p. $179-190$.

LOPES, MA. and FERRARI, SF., 2000. Effects of human colonization on the abundance and diversity of mammals in eastern brazilian Amazonia. Conservation Biology, vol. 14, no. 6, p. 1658-1665. http://dx.doi.org/10.1046/j.1523-1739.2000.98402.x.

MACDONALD, DW., 1996. Social behaviour of captive bush dogs (Speothos venaticus). Journal of Zoology, vol. 239, no. 3, p. 525-543. http://dx.doi.org/10.1111/j.1469-7998.1996.tb05941.x.

MICHALSKI, F., 2010. The bush dog Speothos venaticus and short-eared dog Atelocynus microtis in a fragmented landscape in Southern Amazonia. Oryx, vol. 44, no. 2, p. 300-303. http:// dx.doi.org/10.1017/S0030605309990871.

OLIVEIRA, T., 2009. Distribution, Habitat Utilization and Conservation of the Vulnerable bush dog Speothos venaticus in Northern Brazil. Oryx, vol. 43, no. 2, p. 247-253. http://dx.doi. org/10.1017/S0030605307002347.

SAMPAIO, R., 2007. Efeitos a longo prazo da perda de habitate da caça sobre mamíferos de médio e grande porte na Amazônia Central. Manaus: Universidade Federal do Amazonas. 54 p. Masters Dissertation.

SILVA-JUNIOR, JSS. and SOARES, MCP., 1999. An unexpected new record for the bush dog, Speothos venaticus Lund, 1842, in the Brazilian Amazonian (Carnivora, Canidae). Publicações Avulsas do Instituto Pau Brasil de Historia Natural, no. 2, p. 7-11. 
ZUERCHER, GL., GIPSON, PL. and CARRILlO, O., 2005. Diet and habitat associations of bush dogs Speothos venaticus in the Interior Atlantic Forest of eastern Paraguay. Oryx, vol. 39, no. 1, p. 86-89. http://dx.doi.org/10.1017/ S0030605305000153.
ZUERCHER, GL., SWARNER, M., SILVEIRA, L. and CARILLO, O., 2004. Bush dog Speothos venaticus (Lund, 1842). In SILLEROZUBIRI, C., HOFFMANN, M. and MACDONALD, DW. Canids: foxes, wolves, jackals and dogs. status survey and conservation action plan. Cambridge: IUCN/SSC Canids Specialist Group. 430 p. 